\title{
Weekend versus weekday admissions in Polish stroke centres - could admission day affect prognosis in Polish ischaemic stroke patients?
}

\section{Przyięcia w dni robocze i w weekend na polskich oddziałach udarowych - czy dzień przyięcia wpływa na rokowanie chorych na udar niedokrwienny mózgu w Polsce?}

\author{
Maciej Niewada 1,2, Agnieszka Jezierska-Ostapczuk³, Marta Skowrońska², Iwona Sarzyńska-Długosz², Anna Członkowska 1,2 \\ IKatedra i Zakład Farmakologii Doświadczalnej i Klinicznej, Warszawski Uniwersytet Medyczny \\ 2II Klinika Neurologii, Instyłut Psychiatrii i Neurologii w Warszawie \\ 30ddział Neurologiczny, Szpital Powiatowy w Sokotowie Podlaskim
}

Neurologia i Neurochirurgia Polska 2012; 46, 1: 15-21

DOI: 10.5114/ninp.2012.27209

\begin{abstract}
Background and purpose: Disparities in resources, access to the expertise and healthcare providers both at hospital and before admission, or patients' awareness of stroke symptoms can cause differences in weekend and weekday stroke severity and prognosis. The aim of the study was to explore differences in baseline characteristics and outcomes of ischaemic stroke patients admitted on weekdays and weekends.

Material and methods: A questionnaire based on the WHO Step Stroke and Swedish Stroke Registry was used to collect data on patients admitted to centres participating in the POLKARD Hospital Stroke Registry between June 1 1st $^{\text {st }} 2004$ and May $31^{\text {st }}, 2005$. To ensure the quality, only centres reporting at least 100 patients were analysed. Clinical characteristics and early outcomes (death rate and poor outcome defined as modified Rankin scale score of 3 or above) were compared between patients admitted on weekdays and weekends.

Results: A total of 19667 ischaemic stroke patients, including 5924 admitted during weekends, were reported by 72 stroke centres. Weekend patients were older, more often disabled prior to stroke and more commonly presented with atrial fibrillation and coronary heart disease. Weekend patients were more likely to present consciousness disturbances at
\end{abstract}

\section{Streszczenie}

Wstęp i cel pracy: Czynniki przedszpitalne i szpitalne oraz dostępność wykwalifikowanego personelu i badań diagnostycznych mogą wpływać na rokowanie chorych na udar mózgu. Celem niniejszej pracy jest porównanie charakterystyki i rokowania chorych na udar niedokrwienny mózgu przyjmowanych do szpitala w ciagu tygodnia oraz w weekend. Materiał i metody: Analizowano dane zebrane w Rejestrze Szpitalnym POLKARD prowadzonym od 1 czerwca $2004 \mathrm{r}$. do 31 maja 2005 r., wykorzystując dane jedynie $z$ tych oddziałów, które zgłosiły co najmniej 100 pacjentów. Dane gromadzono w ramach kwestionariusza internetowego przygotowanego na podstawie kwestionariusza udarowego WHO oraz Szwedzkiego Rejestru Udarów Mózgu. Stan kliniczny przy przyjęciu, czynniki ryzyka i wyniki leczenia [zgon oraz niesprawność określona skalą Rankina (mRS)] porównywano wśród pacjentów przyjętych do szpitala w weekend i w ciągu tygodnia.

Wyniki: Na 72 oddziały przyjęto łącznie 19667 chorych z udarem niedokrwiennym, w tym 5924 w weekend. Pacjenci przyjęci na oddziały w weekend byli starsi, mniej sprawni ruchowo, częściej obciążeni migotaniem przedsionków oraz chorobą wieńcową i częściej mieli zaburzenia świadomości

Correspondence address: Anna Cztonkowska, $2^{\text {nd }}$ Department of Neurology, Institute of Psychiatry and Neurology, 9 Sobieskiego Street, 02-957 Warsaw, Poland, phone: +48 2284276 83, fax +48 2284240 23, e-mail: czlonkow@ipin.edu.pl

Received: 31.12.2010; accepted: 27.09.2011 
admission. More patients admitted on weekends died during hospitalization or had poor outcome at discharge than weekday patients $(15.9 \%$ and $59.8 \%$ vs. $14.1 \%$ and $55.3 \%$, respectively). After adjusting for baseline severity of stroke and case-mix, the regression model showed that weekend ischaemic stroke patients had worse prognosis (odds of 1.137 and 1.147 for death and poor outcome, respectively).

Conclusions: Admissions on weekends are associated with higher mortality and poor outcome, and that can be only partially explained by differences in baseline characteristics of admitted patients.

Key words: day of the week, early outcome, fatality, stroke, weekend.

\section{Introduction}

Studies have shown higher mortality among patients admitted with stroke on weekends than on weekdays [1,2]. This weekend phenomenon can result from disparities in resources, expertise and healthcare providers working both in hospital and pre-hospital or patients' awareness of stroke symptoms causing differences in weekend stroke severity. Stroke symptoms should be rapidly addressed by patients or their families and result in fast seeking medical attention. Management of acute stroke syndrome requires urgent diagnostic [3] and therapeutic procedures which may not be uniformly available through the week [4].

Some data suggest that well-organized stroke units may ameliorate the 'weekend effect' due to 24-hour/ 7-day availability of stroke specialists, advanced neuroimaging, or ongoing training and surveillance of specialized nursing care. Also historical data from Sweden suggest that improving stroke care over the decades can be associated with a less significant weekend phenomenon, i.e. excess weekend-admitted patient mortality showed a decreasing trend over time [5].

The aim of our study was to evaluate the impact of weekend admission on stroke mortality in patients hospitalized in Polish stroke centres participating in the National Cardiovascular Disease Prevention and Treatment Program (POLKARD) Hospital Stroke Registry.

\section{Material and methods}

\section{Participating centres and data collection}

All Polish neurological departments (with or without a stroke unit) admitting acute stroke patients were przy przyjęciu. Wśród pacjentów przyjętych do szpitala w weekend odsetek zgonów i niekorzystny wynik leczenia ( $\mathrm{mRS} \geq 3$ ) były istotnie częstsze (odpowiednio 15,9\% i 59,8\% vs $14,1 \%$ i 55,3\% wśród chorych przyjętych w ciagu tygodnia). Po uwzględnieniu różnic w wyjściowym ryzyku w modelu regresji stwierdzono, że przyjęcie do szpitala w weekend pogarsza rokowanie w sposób istotny i niezależny od innych czynników rokowniczych (iloraz szans równy 1,137 i 1,147 odpowiednio dla zgonu i niekorzystnego wyniku leczenia).

Wnioski: Przyjęcie do szpitala w weekend wiąże się z większą śmiertelnością i mniej korzystnym wynikiem leczenia chorych na udar niedokrwienny w Polsce.

Słowa kluczowe: dzień tygodnia, wczesne wyniki leczenia, śmiertelność, udar mózgu, weekend.

invited to participate in the POLKARD Hospital Stroke Registry. All participating centres used the same study protocol and the same study web-based questionnaire. The questionnaire was based on the Swedish Stroke Registry and the WHO STEPS Stroke, step 1, but expanded with additional data on stroke management to meet the requirements for data collection according to the National Cardiovascular Disease Prevention and Treatment Program [6]. Participating centres were provided with definitions used for clinical data collection and randomly selected centres were audited. Data were analysed only for centres which reported at least 100 patients.

\section{Patients}

In the present study prospectively collected data are presented for all hospitalized ischaemic stroke patients who were admitted to centres participating in the POLKARD Hospital Stroke Registry between June the $1^{\text {st }} 2004$ and May $31^{\text {st }} 2005$.

Patients were identified based on admission/discharge codes indicating stroke, i.e. subarachnoid haemorrhages, haemorrhagic stroke, ischaemic stroke and unclassified stroke (I60, I61, I63 and I64 in International Classification of Diseases, $10^{\text {th }}$ revision of the International Classification of Diseases (ICD), respectively). As there is a significant difference in prognosis associated with ischaemic and hemorrhagic stroke, we focused exclusively on ischaemic stroke patients. The cause of ischaemic stroke was classified according to the TOAST criteria [7].

Data were collected on age, gender, previous stroke (only hospital records documenting previous hospitali- 
zation; changes on CT scan without documented symptoms do not allow one to diagnose previous stroke), hypertension (systolic blood pressure $>140 \mathrm{~mm} \mathrm{Hg}$ or diastolic blood pressure $>90 \mathrm{~mm} \mathrm{Hg}$; for diabetic or chronic renal insufficiency patients corresponding values were $>130 \mathrm{~mm} \mathrm{Hg}$ and $>80 \mathrm{~mm} \mathrm{Hg}$, respectively), atrial fibrillation (AF), coronary heart disease (diagnosed by invasive or non-invasive methods), previous myocardial infarction (MI) (only changes diagnosed and treated with ECG at least thirty days before hospitalization due to stroke), diabetes, cholesterol level (total cholesterol level over $200 \mathrm{mg} \%$, LDL cholesterol over $100 \mathrm{mg} \%$, HDL cholesterol below $40 \mathrm{mg} \%$ for males and $50 \mathrm{mg} \%$ for females and triglycerides over $150 \mathrm{mg} \%$ ), smoking (at least one cigarette per day 6 months before stroke), alcohol consumption (over $20 \mathrm{~g}$ of pure alcohol per day) and drugs prior to stroke (recalled by patients or stated in medical records). The registry also collected information on time of stroke onset and time of hospital admission, consciousness on admission, modified Rankin scale (mRS) score before stroke and at discharge, stroke unit-based treatment, drug use, rehabilitation treatment procedures, discharge date and destination, cause of death (defined as death directly related to stroke, stroke complication or stroke comorbidities, death unrelated to stroke and death of unknown cause) [8].

Data were compared for patients admitted on weekdays and weekends. Weekends were defined as admissions on Friday after 3 pm, Saturday and Sunday. Because the study involved de-identified data acquired during routine care, informed consent was not required.

\section{Statistical analysis}

Stroke patients' baseline clinical characteristics, acute stroke care and early outcomes were compared for weekday and weekend patients using the $\chi^{2}$ test for proportions and categorical variables and by using Student's $t$-test for continuous variables.

Cumulative event-free rates for the time to in-hospital death were estimated by the Kaplan-Meier function with the log-rank test.

A Cox regression model for early fatality and a logistic regression model for early outcome defined as poor outcome ( $m R S \geq 3$ ) were developed to adjust for confounders and to compare the risk of death and disability associated with weekend versus weekday ischaemic stroke admissions. Regression models controlled for age, sex, mRS before stroke, history of stroke or transient ischaemic attack (TIA), hypertension, AF, coronary artery disease, history of MI, diabetes, hyperlipidaemia, alcohol abuse, smoking, and consciousness level at admission defined as alert, drowsy, stupor and coma (the only available proxy for stroke severity).

\section{Results}

Seventy-three centres admitting acute stroke patients actively participated in the POLKARD Hospital Stroke Registry. Data from all centres were analysed excluding one because of low quality data collected. A total of 23721 stroke (both ischaemic and haemorrhagic) patients were registered. Ischaemic stroke was diagnosed in 13743 and 5924 weekday and weekend patients, respectively.

\section{Baseline characteristics}

Baseline characteristics of both compared groups are presented in Table 1.

Weekend patients were significantly older (mean age of 71.4 and 70.2 years in weekend and weekdays patients, respectively). Risk factor distributions were similar in both groups, excluding AF and coronary heart disease, reported significantly more often in weekend patients. Pre-stroke disability was more prevalent in weekend than weekday patients.

Weekend patients were more likely to present consciousness disturbances at admission. Weekend stroke admission was associated with shorter time from stroke symptoms onset to hospital arrival (863 and $682 \mathrm{~min}-$ utes for weekday and weekend patients, respectively; $p<0.001)$ and higher number of patients admitted within the first hours after stroke onset. Many patients were reported with unknown time of stroke onset and missing data; thus arrival time interpretation is very limited.

\section{In-hospital management}

The data on in-hospital management are presented in Table 2.

Weekend patients were more likely to be diagnosed with more severe stroke as reflected in TOAST criteria (more cardioembolic and fewer lacunar strokes). More weekend ischaemic stroke patients had no determined aetiology of stroke. 
Table 1. Baseline characteristics of ischaemic stroke patients admitted on weekdays and weekends

\begin{tabular}{|c|c|c|c|}
\hline & $\begin{array}{l}\text { Weekday admissions } \\
\qquad n=13743\end{array}$ & $\begin{array}{l}\text { Weekend admissions } \\
\qquad n=5924\end{array}$ & $P$-value \\
\hline Mean age (SD) & $70.21(12.09)$ & $71.37(11.64)$ & $<0.001$ \\
\hline Females & $7036(51.2 \%)$ & $3058(51.6 \%)$ & 0.586 \\
\hline \multicolumn{4}{|l|}{ Stroke risk factors } \\
\hline history of stroke & $3046(22.2 \%)$ & $1352(22.8 \%)$ & 0.314 \\
\hline history of TIA & $828(6.0 \%)$ & $344(5.8 \%)$ & 0.576 \\
\hline atrial fibrillation & $3204(23.3 \%)$ & $1457(24.6 \%)$ & 0.053 \\
\hline coronary heart disease & $4699(34.2 \%)$ & $2143(36.2 \%)$ & 0.007 \\
\hline history of myocardial infarction & $1497(10.9 \%)$ & $669(11.3 \%)$ & 0.413 \\
\hline hypertension & $9922(72.2 \%)$ & $4318(72.9 \%)$ & 0.322 \\
\hline diabetes & $3283(23.9 \%)$ & $1424(24.0 \%)$ & 0.827 \\
\hline hyperlipidaemia & $3470(25.2 \%)$ & $1435(24.2 \%)$ & 0.132 \\
\hline smoking & $2028(14.8 \%)$ & $840(14.2 \%)$ & 0.301 \\
\hline alcohol & $691(5.0 \%)$ & $331(5.6 \%)$ & 0.107 \\
\hline no risk factors & $972(7.1 \%)$ & $429(7.2 \%)$ & 0.673 \\
\hline \multicolumn{4}{|l|}{$\mathrm{mRS}$ before stroke } \\
\hline 0 & $7676(59.2 \%)$ & $3171(56.7 \%)$ & 0.029 \\
\hline 1 & $2087(16.1 \%)$ & $959(17.1 \%)$ & \\
\hline 2 & $1459(11.2 \%)$ & $635(11.4 \%)$ & \\
\hline 3 & $770(5.9 \%)$ & $354(6.3 \%)$ & \\
\hline 4 & $630(4.9 \%)$ & $297(5.3 \%)$ & \\
\hline 5 & $347(2.7 \%)$ & $176(3.1 \%)$ & \\
\hline $\begin{array}{l}\text { Time from onset to admission (min), } \\
\text { mean (SD) }\end{array}$ & $863(1948)$ & $682(1467)$ & $<0.001$ \\
\hline $\begin{array}{l}\text { Patients with known time of stroke onset } \\
\text { admitted within first } 3 \text { hours }\end{array}$ & $2199(16.0 \%)$ & $1010(17.0 \%)$ & 0.02 \\
\hline $\begin{array}{l}\text { Patients with known time of stroke onset } \\
\text { admitted within first } 6 \text { hours }\end{array}$ & $1373(10.0 \%)$ & $621(10.5 \%)$ & \\
\hline \multicolumn{4}{|l|}{ Consciousness level on admission: } \\
\hline alert & $10570(76.9 \%)$ & $4439(74.9 \%)$ & 0.01 \\
\hline drowsy & $2073(15.1 \%)$ & $930(15.7 \%)$ & \\
\hline stupor & $697(5.1 \%)$ & $365(6.2 \%)$ & \\
\hline coma & $401(2.9 \%)$ & $189(3.2 \%)$ & \\
\hline
\end{tabular}

$S D$ - standard deviation, TIA - transient ischaemic stroke, mRS - modified Rankin scale

Weekend patients used fewer vasoactive agents, The use of aspirin and blood pressure lowering agents and were more often treated with heparins and antibiotics $(29.6 \%$ and $31.45 \%$ compared to was similar in both groups after adjusting for stroke $28.0 \%$ and $27.9 \%$ of weekday patients, respectively). subtype and hypertension rate (data not presented in tables). 
Table 2. In-hospital management of ischaemic stroke patients admitted on weekdays and weekends

\begin{tabular}{|c|c|c|c|}
\hline & $\begin{array}{l}\text { Weekday admissions } \\
n=13743\end{array}$ & $\begin{array}{l}\text { Weekend admissions } \\
\quad n=5924\end{array}$ & $P$-value \\
\hline \multicolumn{4}{|c|}{ Ischaemic stroke aetiology - TOAST criteria } \\
\hline large-artery atherosclerosis & $4994(36.3 \%)$ & $2169(36.6 \%)$ & $<0.001$ \\
\hline cardioembolism & $1826(13.3 \%)$ & $867(14.6 \%)$ & \\
\hline small-vessel occlusion & $2718(19.8 \%)$ & $1022(17.3 \%)$ & \\
\hline stroke of other determined aetiology & $1068(7.8 \%)$ & $448(7.6 \%)$ & \\
\hline stroke of undetermined aetiology & $3135(22.8 \%)$ & $1417(23.9 \%)$ & \\
\hline Thrombolysis & $93(0.7 \%)$ & $38(0.6 \%)$ & 0.844 \\
\hline Antihypertensives & $9876(71.9 \%)$ & $4316(72.9 \%)$ & 0.155 \\
\hline Aspirin & $10803(78.6 \%)$ & $4652(78.5 \%)$ & 0.910 \\
\hline Oral anticoagulants & $1328(9.7 \%)$ & $573(9.7 \%)$ & 0.980 \\
\hline Heparins & $3844(28.0 \%)$ & $1755(29.6 \%)$ & 0.019 \\
\hline Statins & $4119(30.0 \%)$ & $1726(29.1 \%)$ & 0.241 \\
\hline Antibiotics & $3841(27.9 \%)$ & $1861(31.4 \%)$ & $<0.001$ \\
\hline
\end{tabular}

\section{Early outcome}

Early outcomes are presented in Table 3.

Ischaemic stroke patients admitted on weekends, although they spent a similar number of days at hospital, more often died or were disabled at discharge and were less likely to return home.

Kaplan-Meier curves demonstrated higher case fatality of ischaemic stroke patients admitted on weekends then weekdays ( $p=0.0006$; log-rank test; Fig. 1 ). Regression models showed that weekend ischaemic stroke patients had worse prognosis: odds of 1.137 $(p=0.0068)$ and $1.147(p=0.0003)$ for death and poor outcome, respectively.

\section{Discussion}

Poorer prognosis for weekend stroke patients can result from two main causes. The first is pre-hospital driven reasons, encompassing stroke symptoms awareness, stroke severity and pre-hospital care; and the second is associated with in-hospital care. In our study, only some aspects could be addressed as data were limited.

Weekend patients were older, more likely to have AF or coronary heart disease, were more disabled prior to stroke and suffered more severe stroke (less lacunar stroke, more cardioembolic stroke and more often consciousness disturbances), which corresponds to more urgent medical seeking and shorter mean time from onset to admission. The inverse relation between stroke severity and time from onset to admission should support social educational activities aimed at stroke symptoms awareness regardless of severity. Uncontrolled risk factors can increase stroke severity and that should also be communicated.

Pre-hospital care organization can affect less severe stroke patients seeking care. Lasserson et al. [9] found that limited access to general practitioners outside regular opening hours can increase the delay in assessment of TIA and minor stroke. Fast and professional assessment of stroke patients should be accompanied by an effective transport and stroke unit referral system.

Fewer than $1 \%$ of patients were reported to be treated with thrombolysis in both groups, as rt-PA treatment at that time in Poland was hardly available and was only being implemented [10]. Although weekend patients were more likely to arrive within the first 3 or 6 hours after stroke onset, it has not resulted in more rt-PA treatment procedures. Either pre-hospital or in-hospital care determines the rt-PA treatment feasibility, and both need to be pooled to delivered patients with an opportunity to receive benefit from this effective therapy. More severe stroke resulting in earlier presentation to hospitals and possibly quicker access to diagnostic imaging and tests can explain the slight weekend effect on thrombolytic use (weekend compared with weekday patients 
Table 3. Early outcomes of ischaemic stroke patients admitted on weekdays and weekends

\begin{tabular}{|c|c|c|c|}
\hline & $\begin{array}{l}\text { Weekday admissions } \\
n=13743\end{array}$ & $\begin{array}{l}\text { Weekend admissions } \\
\quad n=5924\end{array}$ & $P$-value \\
\hline Hospital stay - days; mean (SD) & $12.34(9.948)$ & $12.5(9.745)$ & 0.269 \\
\hline Stroke unit stay $(\%)$ & 84.2 & 84.6 & 0.547 \\
\hline \multicolumn{4}{|l|}{$\mathrm{mRS}$ at discharge } \\
\hline 0 & $945(6.9 \%)$ & $342(5.8 \%)$ & \multirow[t]{6}{*}{$<0.001$} \\
\hline 1 & $2925(21.3 \%)$ & $1116(18.8 \%)$ & \\
\hline 2 & $2539(18.5 \%)$ & $1015(17.1 \%)$ & \\
\hline 3 & $1785(13.0 \%)$ & $763(12.9 \%)$ & \\
\hline 4 & $2032(14.8 \%)$ & $979(16.5 \%)$ & \\
\hline 5 & $2001(14.6 \%)$ & $941(15.9 \%)$ & \\
\hline Poor outcome (mRS $\geq 3$ ) & $7334(53.4 \%)$ & $3451(58.3 \%)$ & $<0.001$ \\
\hline Death rate & $1516(11.0 \%)$ & $768(13.0 \%)$ & $<0.001$ \\
\hline \multicolumn{4}{|l|}{ Causes of death $(\%)$} \\
\hline unknown reason & $49(3.3 \%)$ & $21(2.8 \%)$ & \multirow[t]{6}{*}{0.275} \\
\hline stroke directly related & $732(48.8 \%)$ & $369(48.5 \%)$ & \\
\hline due to stroke associated complications & $387(25.8 \%)$ & $192(25.2 \%)$ & \\
\hline $\begin{array}{l}\text { indirectly associated with stroke; } \\
\text { caused by comorbidities }\end{array}$ & $278(18.5 \%)$ & $150(19.7 \%)$ & \\
\hline not caused by stroke & $48(3.2 \%)$ & $29(3.8 \%)$ & \\
\hline other & $6(0.4 \%)$ & 0 & \\
\hline \multicolumn{4}{|l|}{ Destination (\%) } \\
\hline home & $9477(78.5 \%)$ & $3880(76.1 \%)$ & \multirow[t]{5}{*}{$<0.001$} \\
\hline nursing home & $443(3.7 \%)$ & $192(3.8 \%)$ & \\
\hline rehabilitation unit & $1149(9.5 \%)$ & $511(10.0 \%)$ & \\
\hline residential home, long institutional care & $297(2.5 \%)$ & $163(3.2 \%)$ & \\
\hline other hospital department & $711(5.9 \%)$ & $353(6.9 \%)$ & \\
\hline
\end{tabular}

$S D$ - standard deviation; $m R S$ - modified Rankin scale

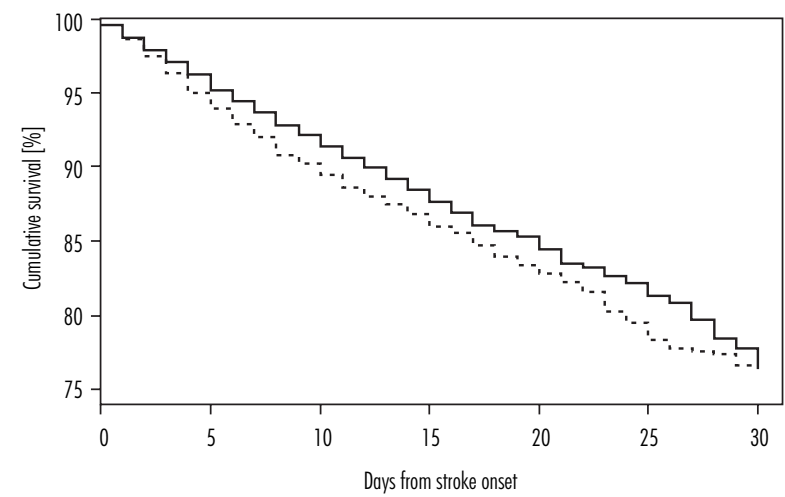

Fig. 1. Kaplan-Meier survival curves for weekdays (solid line) and weekend (dotted line) admitted ischaemic stroke patients; log-rank test $p$-value $=0.0006$ with stroke were slightly more likely to receive thrombolytics), as reported by Hoh et al. [11].

After adjusting for case-mix, the risk of early death and poor outcome were higher for ischaemic stroke patients admitted at weekends. Our estimations are very similar to that reported by Fang et al. [12], who found a hazard ratio of 1.12 for all-cause 7-day fatality rates in stroke patients seen on weekends compared to weekdays after adjustment for age, sex, stroke severity, and comorbid conditions.

The difference in prognosis can also result from the quality of in-hospital care, i.e. less availability of medical staffing, thrombolytic therapy [13] and ancillary support $[14,15]$. Thus efforts need to be made to pro- 
vide stroke patients with high quality care regardless of operating hours. A study by Albright et al. [16] showed that a comprehensive stroke centre with 24-hour/7-day availability of stroke specialists, advanced neuroimaging, or ongoing training and surveillance of specialized nursing care, can ameliorate the 'weekend effect' in stroke patients. Higher stroke death among weekend patients can also result from referral bias, as postulated by Turin et al. [17], and it was not controlled for in our study. The higher mortality can also result from more infectious complications in weekend stroke patients and that from in-mobility as suggested by higher use of antibiotics and heparins.

The limitation of our study is the lack of data on quality of pre-hospital and in-hospital care as well as long-term outcome data. It should also be stressed that data presented and analysed represent the years 2004 and 2005 . Since that time, stroke healthcare has developed and currently one can expect better medical service available 24 hours/7 days [18]. Thus, it is crucial to continue monitoring of the weekend effect as a quality proxy of stroke healthcare provided in Poland.

\section{Conclusions}

1. Admissions on weekends are associated with higher mortality and poor outcome and can be partially explained by differences in baseline characteristics of admitted patients.

2. Not only patients' awareness of stroke symptoms, but also pre-hospital and hospital stroke service should be improved to ensure the appropriate care for patients with stroke.

\section{Acknowledgments and funding}

The chief acknowledgement is to the centres and doctors participating in the POLKARD Hospital Stroke Registry.

The study was supported by an unrestricted scientific grant from the Polish Ministry of Health, National Cardiovascular Disease Prevention and Treatment Program - POLKARD 2003-2005.

\section{Disclosure}

No potential conflict of interest relevant to this article was reported.

\section{References}

1. Saposnik G., Baibergenova A., Bayer N., et al. Weekend: a dangerous time for having a stroke? Stroke 2007; 38: 1211-1215.

2. Hasegawa Y., Yoneda Y., Okuda S., et al; Acute Stroke Rehabilitation Study Group. The effect of weekends and holidays on stroke outcome in acute stroke units. Cerebrovasc Dis 2005; 20: 325-331.

3. Fogelholm R., Murros K., Rissanen A., et al. Factors delaying hospital admission after acute stroke. Stroke 1996; 27: 398-400.

4. Williams L.S., Bruno A., Rouch D., et al. Stroke patients' knowledge of stoke. Stroke 1997; 28: 912-915.

5. Janszy I., Ahnve S. Weekend versus weekday admission and stroke outcome in Sweden from 1968 to 2005. Stroke 2007; 38: e94.

6. Członkowska A., on behalf of Polish Experts of the Prevention and Treatment of Cerebrovascular Diseases Programme. European Stroke Initiative: stroke management. Neurol Neurochir Pol 2001; 35 (Suppl 6): 5-10.

7. Warlow C.P. Epidemiology of stroke. Lancet 1998; 352 (Suppl 3): 1-4.

8. http://www.who.int/ncd_surveillance/steps/stroke/en/steps stroke_manual(v1.4).pdf.

9. Lasserson D.S., Chandratheva A., Giles M.F., et al. Influence of general practice opening hours on delay in seeking medical attention after transient ischaemic attack (TIA) and minor stroke: prospective population based study. BMJ 2008; 337: a1569. doi: 10.1136/bmj.a1569.

10. Kobayashi A., Członkowska A., Ahmed N., et al. Intravenous recombinant tissue plasminogen activator for acute stroke in Poland: An analysis based on the Safe Implementation of Thrombolysis in Stroke (SITS) registry. Acta Neurol Scand 2010; 122: 229-236.

11. Hoh B.L., Chi Y.-Y., Waters M.F., et al. Effect of weekend compared with weekday stroke admission on thrombolytic use, in-hospital mortality, discharge disposition, hospital charges, and length of stay in the nationwide inpatient sample database, 2002 to 2007. Stroke 2010; 42: 2323-2328.

12. Fang J., Saposnik G., Silver F.L., et al. Association between weekend hospital presentation and stroke fatality. Neurology 2010; 75: 1589-1596.

13. Lees K.R., Ford G.A., Muir K.W., et al. Thrombolytic therapy for acute stroke in the United Kingdom: experience from the safe implementation of thrombolysis in stroke (SITS) register. QJM 2008; 101: 863-869.

14. Manfredini R. Higher stroke mortality on weekends: are all strokes the same? Stroke 2007; 38: e112.

15. Rudd A.G., Hoffman A., Down C., et al. Access to stroke care in England, Wales and Northern Ireland: the effect of age, gender and weekend admission. Age Ageing 2007; 36: 247-255.

16. Albright K., Raman R., Ernstrom K., et al. Can comprehensive stroke centers erase the 'weekend effect'. Cerebrovasc Dis 2009; 27: 107-113.

17. Turin T., Kita Y., Rumana N., et al. Case fatality of stroke and day of the week: is the weekend effect an artifact? Cerebrovasc Dis 2008; 26: 606-611.

18. Sarzyńska-Długosz I., Skowrońska M., Członkowska A. Development of the stroke unit network in Poland - current status and future requirements. Neurol Neurochir Pol 2007; 41: 107-112. 